\title{
THE D\&O LIABILITY INSURANCE POLICY IN THE SMALL CORPORATION
}

\author{
Kenneth W. Hollman \\ Martin Chair of Insurance \\ Middle Tennessee State University \\ Murfreesboro, Tennessee \\ H. Ronald Moser \\ Director, Small Business Institute \\ Middle Tennessee State University \\ Murfreesboro, Tennessee \\ Joe H. Murrey \\ Director, Insurance Excellence Program \\ University of Mississippi \\ Oxford, Mississippi
}

At one time, service on the board of directors of a corporation was the ul timate status symbol-an accolade that businesses paid successful and leading citizens. Duties were light and the rewards, both emotional and financial, were substantial. Risk was almost nonexistent. Directors did not often direct, and few were held accountable for not doing so ([4],[5]). However, the situation has changed in recent years. Officers and directors are increasingly held accountable as fiduciaries. If a cause of action exists-perhaps due to a thoughtless slip or blunder-the director or officer may be exposed to personal liability in large amounts. Ultimately, a personal liability claim could place all of a director's or officer's assets at risk.

The risk of liability faced by the executives of even small corporations can be great. Directors and officers of small corporations face suits by employees, stockholders, regulators, customers, and clients, just like their counterparts in larger ones. The risk is probably greater for directors and officers in large companies. However, there may be a greater likelihood in small corporations of claims arising from disputes between and among directors and officers, particularly in closely held family firms. Also, small corporations are more likely than larger ones to be new, and they have higher failure rates. Directors and officers are sometimes held accountable for such failures. In addition, small corporations are probably at least as susceptible as larger ones to merger, acquisition, or takeover attempts, which often precipitate lawsuits against directors and officers by disgruntled stockholders.

Several articles and books have been written on the underlying substantive liabilities of directors and officers $([1],[2],[7],[8])$, but there is less information 
concerning protection for them against the financial consequences of their wrongful acts. ${ }^{1}$ Most of the writings available are shaped in light of information on large corporations, with little consideration for small ones. The purpose of this paper is to close this informational gap by acquainting directors and officers of small corporations with techniques to handle loss exposures arising from alleged breaches of duty in their official capacities as directors and officers.

The paper is divided into four sections. The first section discusses the two main alternatives available to the director or officer to deal with lawsuits brought against them: reimbursement by the corporation and the transfer of risk by insurance. The second section contains a discussion of recent trends in directors' and officers' liability insurance, including a tightening of the market that has forced premium rates upward and reduced available limits. The third section provides helpful hints for corporate managers who are thinking of purchasing such policies, and the fourth section contains the summary and conclusions of the paper.

\section{Legal Protection for Directors and Officers}

While directors and officers face potentially severe consequences for wrongful acts, they do have certain financial defenses available. First, they may look to the corporation, which may reimburse (indemnify) them for economic loss resulting from lawsuits. Second, they may look to specialized insurance contracts which provide a substantial measure of protection against gaps in coverage via corporate reimbursement. These alternative means of protection are discussed in turn below.

\section{Indemnification by Company}

Corporate reimbursement to directors and officers for their economic loss due to a successful legal challenge is authorized by statute in every state. Some states permit flexibility as to whether such payments will be made, while others make them mandatory. When a defense against an alleged wrongful act is successful, there is certainly nothing improper in the reimbursement of an officer or director by the corporation. Even when a defense is unsuccessful, repayment of expenses will often be sustained, and reimbursement for judgments and amounts paid in settlement are sometimes permitted, depending on the circumstances of the particular case $([6],[9],[10])$.

\footnotetext{
'The leading wrongful act allegation in director's and officer's (D\&O) litigation is misleading representation. This may take the form of false or misleading statements in prospectuses, communications to stockholders, or registration statements. This class of wrongful act comprised 25 percent of all allegations of wrongful conduct in 1984. The second most common allegation in D\&O claims in 1984 was collusion or conspiracy to defraud, accounting for 12 percent of all claims. An example of an alleged offense under this category would be conspiracy by directors and officers with the corporation in violation of the federal criminal conspiracy statutes. In descending order of frequency, the following types of allegations accounted for seven percent or more of all $D \& O$ suits in 1982: improper expenditures, breach of duty to minority stockholders, antitrust violations, interference with contractual rights, civil rights denial, and conflict of interest [18].
} 
It is important to note that corporate reimbursement is not always available to directors and officers for protection against defense costs and damage awards or settlements. For example, there are areas of liability for corporate managers that are not indemnifiable. These include judgments or settlements in actions brought by stockholders where the court finds gross negligence, and liabilities for violations of federal securities laws. To this should be added those cases in which the corporation cannot indemnify because it is bankrupt or goes out of existence. To protect against gaps in coverage afforded by reimbursement statutes, or failure by the corporation to provide reimbursement, executives are advised to consider the purchase of directors' and officers' liability insurance (D\&O insurance) $([6],[7],[16])$.

\section{Directors' and Officers' Liability Insurance}

$D \& O$ insurance is a specialized type of professional liability coverage designed to protect a director or officer of a firm for liability due to breaches of duty resulting from negligence. ${ }^{2}$ It remains one of the least understood types of insurance coverage because of the intricacy of the D\&O contract and the complex situations in which it is asked to respond.

Insuring Clause. The insuring clause or insuring agreement is the heart of any insurance contract. In the insuring clause of the D\&O policy, the insurer agrees to pay on behalf of the insured for a loss or claim from actual or asserted wrongful acts that occur during the policy period. No reference is made to judgment in most $\mathrm{D} \& \mathrm{O}$ insuring clauses. Contracts are framed to cover lack of good business acumen $([6],[7],[13])$.

The D\&O contract covers losses due to judgments and settlements as well as costs of defense and appeals. Subject to policy conditions and exclusions, the insured (defendant) may recover from the insurer even if the plaintiff wins the case $([7],[12])$.

Coverages. There is no standardization of the insurance written for D\&O coverage, but carriers consider the exposure from two points of view. That is, the $\mathrm{D} \& \mathrm{O}$ policy provides hybrid coverage and is typically issued with two coverage sections. The first is called "corporate reimbursement coverage" and the other is called "directors' and officers' coverage" or "personal coverage." These coverages are discussed briefly below.

Corporate reimbursement coverage responds to indemnify the insured corporation for business-related legal fees or judgments that it incurs as a result of the indemnification it pays its directors and officers for their wrongful acts. In effect, corporate reimbursement coverage insures the corporation's obligations to repay its directors and officers where it is permitted or required to do so. D\&O policies usually do not protect the corporate entity itself for direct actions which a plaintiff may bring against it.

\footnotetext{
${ }^{2}$ Negligence involves the failure to act as a reasonable and prudent person would have acted in similar circumstances, or doing what a prudent person would not have done.
} 
Corporate reimbursement coverage is obtained and paid for by the corporation. All of the directors and officers in positions that are named in the contract are included in the coverage on a blanket basis. The contract also covers new positions that are created during the term of the policy, as well as new appointees to either new or old positions ([2],[6],[7]).

Personal coverage is the second part of the dual-form D\&O policy. It is much more important to the individual director of officer, since they are most interested in protecting themselves in those cases where corporate reimbursement coverage is inapplicable, i.e., where the corporation cannot or will not indemnify them. For example, an unsuccessful director or officer defendant in a suit brought by the corporation for fraud is hardly in a position to ask the corporation (which has just won the suit) to reimburse him/her for defense costs and the award he/she is ordered to pay. For a single loss, personal coverage would not apply if corporate coverage applied.

Personal coverage protects directors and officers in the same named positions as would corporate reimbursement coverage, and the scope of coverage is similar for both. However, under the personal coverage provision, the indemnification is made directly to the director or officer for those sums for which he or she may become liable while acting in an official capacity. The premium cost for personal coverage is sometimes paid by the individual executive, in which case it is a tax-deductible item on the executive's personal income tax return, but it is usually paid by the corporation if the law permits $([2],[7],[8])$.

Claims-Made Coverage. The D\&O policy provides coverage for wrongful acts of directors and officers that occur during the policy period if suit is brought during the policy period and proper notice is given. That is, the D\&O policy is a "claims-made" policy. However, upon cancellation or nonrenewal the insured should report to the carrier any incident or situation that might give rise to a claim. Then, any claim made after expiration/cancellation that arises out of the information reported will be treated as a claim made during the policy period.

As noted above, there is no coverage for a claim brought after cancellation or non-renewal, unless circumstances surrounding the claim were previously reported to the carrier. However, there is a way in which directors and officers may protect themselves in these situations. Through the use of an endorsement, coverage may be extended for up to 12 months beyond the cancellation or expiration date for wrongful acts alleged to have been committed during the policy period. Inclusion of this extended-coverage endorsement in the policy has traditionally involved a cost of about 25 percent of the three-year premium, but this cost has risen in the past two years $([6],[10],[16])$.

Exclusions. A lot of fine print and a number of exclusion clauses complicate the $\mathrm{D} \& \mathrm{O}$ contract. The most common exclusion is for any claim that can be covered under other insurance. $D \& O$ insurance is a form of business malpractice insurance and coverage is very broad, but the $D \& O$ policy is not a single global corporation legal liability policy. Claims based on damage to 
tangible property or on any type of bodily injury, disease, sickness, or death are excluded from all D\&O policies. Many of these types of claims can be covered by other policies such as worker's compensation insurance, property insurance, or general liability insurance policies.

Many D\&O policies deny coverage for directors acting as fiduciaries (managers) of a pension or retirement plan. Others insert a rider or special endorsement (with an additional premium) to the basic policy to cover some or all of any additional liability which directors face because of service on pension or retirement plans. A company not adding an endorsement or rider has the option of purchasing a separate insurance policy covering executives who act as plan fiduciaries.

Other exclusions that are common in newer D\&O contracts are those relating to seepage or to pollution, contamination, or nuclear hazards. D\&O carriers do not want to provide coverage for environmental impairment or nuclear disaster, which can be obtained in other policies. Also, there is an exclusion in most $D \& O$ contracts when the suit is brought by a person covered by the policy. The purpose of this exclusion is to deny coverage when one stockholder group is fighting another for control of the corporation.

Another exclusion relates to any claim arising from a dishonest or criminal act of a director. The denial is based on the premise that acts harmful to the public interest should not be insured or reimbursed. Finally, there is an exclusion for any claim based on the failure of directors to maintain an adequate program of insurance for the corporation. This mandate is included to promote the sale of other forms of insurance and to prevent the D\&O contract from becoming a general, all-risk liability insurance policy $([6],[14],[15])$.

Deductibles and Coinsurance. Typically, the deductibles in the D\&O policy are split between the two major coverages. The deductible on the personal coverage is usually lower than the deductible for the corporation itself on the corporate reimbursement coverage. The deductible must be borne by the insured and not be reinsured.

Coinsurance provisions in many D\&O policies state that the carrier will pay a certain percent of each loss in excess of the retention, and that the insured will pay the remainder. The retention by the insured is typically five percent. However, it is sometimes possible to negotiate the elimination of the five percent coinsurance provision for coverages beyond certain limits, though underwriters have become increasingly reluctant to do so, particularly for smaller corporations. As with the deductible, coinsurance participation may not be insured with another carrier $([7],[10],[13])$.

\section{Recent Trends in D\&O Coverage}

The D\&O market is currently in a state of turmoil that has impacted the cost and availability of coverage. In some cases this has affected the ability of corporations to stay in business. Several trends which have resulted from this crisis are noted below. 


\section{Retention}

There is an increasing tendency for insurance companies to assume a smaller portion of the risk for directors' and officers' liability. Underwriters look favorably on the corporate client that is willing to share some of the risk with the carrier. The risk can be shared through an increase in the deductible or through reduction of coverage limits.

Carriers began to increase the deductible when market conditions tightened in the early 1980's. The increase was most often imposed on the corporate reimbursement provision of the coverage. This has proven particularly damaging to small corporations, since 95 percent of all $D \& O$ claims fall under the corporate reimbursement provision of the policy $([3],[17],[18])$. Simultaneous with the increase in deductible, carriers began to lower coverage limits in a further effort to restrict loss exposure. One large carrier that specializes in $D \& O$ coverage for small corporations now has a $\$ 10,000,000$ coverage limit along with a $\$ 1,000$ deductible per individual director and officer. These retention levels are probably near the norm for the industry $([3],[6],[20])$.

\section{Coverage and Company Size}

$\mathrm{D \& O}$ insurance protection remains more predominant among larger corporations than smaller ones, and the prevalence of coverage rises with the size of the organization. A partial explanation is that there is a high correlation between company size and the frequency of liability claims against directors and officers--medium and large companies are sued more often than small ones. Only 62 percent of the corporations with less than $\$ 25$ billion in assets purchase $D \& O$ protection, and less than half the small businesses in certain industry categories purchase this coverage $([17],[20])$.

\section{Rates}

D\&O premiums were at one time very low. Some corporations purchased $D \& O$ insurance in the 1960's at prices not much greater than for a personal line automobile policy. The situation changed in the 1980's as lawsuits proliferated and the amount of court awards and settlements increased. Some insurers withdrew from the hardening market, forcing long-time clients to fend for themselves in an increasingly hostile environment. For those carriers that remained, renewal prices were often a multiple of expiring prices. Along with higher rates came underwriter-mandated restrictions and exclusions that greatly limited coverage.

Significant differences exist in D\&O premium rates between large and small corporations. Premium rates are proportionately higher for larger ones. However, rates tend to vary greatly even between companies of the same size. The amount a company pays depends, as in other lines of insurance, on the degree of exposure. The policy limits being afforded, vulnerability to legal action, the deductible and retention arrangements, past adverse publicity, and corporate profitability help determine the rates for a particular company. Small closely-held (family owned) companies usually pay more than small 
publicly-held ones because they are subject to domestic feuds ([2],[11],[19]).

Many directors' and officers' liability cases are settled out of court since corporations and their directors seek to avoid adverse publicity and to settle contested issues as quickly as possible. Given the usually slow court process, a protracted case can damage a company's expansion plans, its stock market rating, and its relations with creditors. If a company loses a suit, this may force its D\&O rates up, if it can get such coverage at all. Also, a lawsuit can be harmful both professionally and financially to the directors and officers involved. Therefore, corporate executives may prefer to avoid a public fight and settle out of court, if at all possible, even if they feel they are innocent.

\section{Buyer's Checklist}

Economic realities indicate the the officer in charge of the small corporation's insurance program should exercise great care in the purchase of $D \& O$ liability insurance. The following suggestions and strategies may help that person in designing a professional liability risk management program for the protection of directors and officers.

First, the application for $D \& O$ insurance should be filled out very carefully. Policies typically contain restrictive language that limits the response for any wrongful act that took place prior to policy inception if any insured director or officer knew of that act. Questions about knowledge of such prior acts should not be answered with a simple yes or no, but should be explained in detail. The corporation should utilize internal and external counsel in all phases of policy negotiation, particularly with respect to policy wording.

Second, the buyer of D\&O coverage should request a quote from several different carriers. The pricing is uncontrolled and premium quotations vary significantly from company to company. Senior management should keep itself informed of specific conditions in the market (price, availability, new exclusions) as well as the stability (likelihood of renewal) of the company's own placement.

Third, the renewal time frame should be reasonable for the broker or insurance carrier. Renewal information should be in the broker's or carrier's hands no less than 120 days prior to policy expiration, to provide the broker or carrier with adequate time to prepare a renewal quotation. Then, the corporation should insist upon the receipt of the renewal quotation no less than 45 days prior to expiration. Timing is very important to insure that coverage is continuous.

Fourth, senior executives of small corporations in particular should ask the insurer to quote premium rates for coverage on directors and officers who, in the general interest and as a service to the subject corporation, sit on the boards of other profit or nonprofit corporations. At one time, this extension of coverage was quite common. However, in today's tight market, underwriters are becoming increasingly reluctant to offer it $([3],[15],[21])$. 


\section{Summary and Conclusion}

D\&O liability insurance is the vehicle most frequently used to safeguard corporate officers and directors against the potential legal liability resulting from their managerial errors and omissions. Despite the obvious need for D\&O protection, a significant percentage of small businesses operate without it. Many small businesses feel that they are operating fairly and honestly and see no need to purchase coverage to protect their officers and directors. However, executives of small as well as large corporations face potentially severe liability exposures, and the exposures may be as great for the directors and officers of small corporations as for those of larger ones.

The market for $D \& O$ insurance has been very unstable in the past two years. Renewal premiums have skyrocketed, policy limits have dropped dramatically, and nonnegotiable limitations and exclusions have become commonplace. While the full impact of the turbulence in the D\&O marketplace is difficult to determine, one effect is that directors of many corporations, small as well as large, are choosing to leave their positions. Those who stay are exercising greater care in the execution of their duties and insisting on adequate protection for themselves against charges of breach of duty or other wrongful acts. Candidates for boards are concerned about becoming embroiled in legal entanglements that might place their personal assets at risk.

Reluctance by individuals with management experience to serve on boards of directors could be devastating to many small businesses. Small corporations are often unable to attract highly qualified board members as quickly and easily as larger ones because their board positions offer less prestige. However, small businesses must be able to get top-notch directors to serve on their boards if they are to survive in today's highly competitive economy. As a corollary, those serving on boards should be free to make decisions regarding the business without fear of legal consequences. Simply put, D\&O insurance should be available to directors and officers at reasonable prices and without overly restrictive coverage. Otherwise, it will become increasingly difficult for small corporations to induce competent businesspeople to serve on their boards of directors.

\section{References}

1. Bisler, Roland M. "The Board of Directors: Major Functions and Responsibilities." American Business Review, January, 1985, pp. 29-34.

2. Brockmeier, Warren G. "Directors' and Officers' Liability." Professional Liability: Impact in the Eighties. Malvern, PA: The Society of Property and Casualty Underwriters, Fall, 1983.

3. Clarke, Richard C. 'Negotiating D\&O Without Losing Coverage." Risk Management, August, 1985, pp. 20-24.

4. Dentzer, Susan and Wang, Penelope. "Empty Seats On The Board." Neusweek, August 5, 1985, p. 46. 
5. Fitch, Thomas P. "The Heat Is On." United States Banker, June, 1985, pp. 32-34.

6. Gawel, Michael S., Jain, Jagat P., and Agnello, Vincent. "Directors' and Officers' Indemnification Insurance: What Is Being Offered?" Journal of the American Society of $C L U$, November, 1985, pp. 92-101.

7. Johnston, Joseph F., Jr. Protecting the Corperate Officer and Director from Liability. New York: Practicing Law Institute, 1979.

8. Knepper, William E. Liability of Corporate Officers and Directors. Indianapolis, IN: The Allen Smith Co., 1978.

9. Leisner, Richard M. "Boardroom Jitters: A Landmark Court' Decision Upsets Corporate Directors." Barron's, April 22, 1985, pp. 34-38.

10. McHugh, Thomas M. "Do Directors and Officers Need Liability Coverage?" Financial Executive, April, 1980, pp. 42-48.

11. McIntire, Kathryn J. "Acquisition, Liquidation Force New D\&O Plans." Business Insurance, April 25, 1980, p. 46.

12. Nicolson, Miklos. Duties and Liabilities of Corporate Officers and Directors. Englewood Cliffs, N.J.: Prentice Hall, Inc., 1972.

13. Read, William E. Corporate Officers' and Directors' Handbook. Englewood Clifts, N.J.: Prentice-Hall, Inc., 1980.

14. Rubin, Harvey W. "An Analysis of Directors' and Officers' Liability Exposures and Appropriate Insurance Coverages." Louisiana Business Review, May, 1977, pp. 1-4.

15. Salvatico, Albert L. "Negotiating D\&O Coverage That Fits The Risk." Risk Management, January, 1986, pp. 16-19.

16. Siver, Edward W. The Executive Guide To Commencial Property and Casualty Insurance. Chicago, IL: Crain Books, 1981.

17. Taravello, Steve. "Directors' and Officers' Insurance." Small Business Report, April, 1985, p. 29.

18. Taravello, Steve. "Firms Hiked D\&O Limits During 1984, Study Says." Business Insurance, January 21, 1985, pp. 1; 24.

19. Taravello, Steve. "Large Banks Exploring Coverage Alternatives." Business Insurance, July 22, 1985, pp. 1; 83.

20. Taravello, Steve. "Many Small Businesses Ignore D\&O Risk." Business Insurance, December 10, 1984, pp. 30-31.

21. Taravello, Steve and Shapiro, Stacy. "Pssst... Do You Know a D\&O Insurer?" Business Insurance, July 29, 1985, pp. 1; 29. 